\title{
Sexual Satisfaction among Infertile Spouses in Erbil City
}

Nergz Bayiz Abdulrehman; Department of Nursing, College of Nursing, Hawler Medical University, Erbil, Iraq. (Correspondence: nergiz.bayz89@gmail.com )

Tiran Jamil Piro; Department of Midwifery, College of Nursing, Hawler Medical University, Erbil, Iraq.

\section{ABSTRACT}

Background and objectives: Sexual satisfaction is an emotional state that occurs with the fulfillment of individual wishes in the area of sexual life. Sexual satisfaction is mainly affected by the outcomes of infertility. The study aimed to assess sexual satisfaction among infertile spouses in Erbil city and to determine associations between sexual satisfaction and their sociodemographic characteristics.

Methods: A cross sectional study was conducted on 150 infertile couples visiting Maternity Teaching Hospital and three private infertile centers in Erbil city. Index of sexual satisfaction was used to assess sexual satisfaction. Verbal informed consent was obtained from all participants. Data was analyzed by using the frequency, percentage, Chi-square test and Fisher's exact test from the Statistical Package for Social Sciences version 22.

Results: Three hundred persons (150 infertile couples) participated in the study. Their mean age was $31.82+6.60$ years, ranging from 17 to 49 years old.

More than half of participants were less satisfied, with wives being less satisfied than their husbands. No significant association was detected between sexual satisfaction scores and level of education, occupation income and residency.

Conclusion: The findings of the study indicated that more than half of participants were less satisfied, and wives were less satisfied than their husband. Infertile spouses especially wives should be educated to increase their awareness regarding sexual issues.

Keywords: Sexual satisfaction; Infertility; Spouses.

\section{INTRODUCTION}

Infertility is defined as the inability to conceive after one year of regular, unprotected sexual intercourse. It is a common problem with an estimated $10-15 \%$ prevalence rate worldwide. This common problem might have an important effect on the sexual lives of couples. Additionally, infertility work-up and treatment is a deeply stressing experience for many couples. Approximately $15 \%$ of all couples experience difficulty to conceive after 1 year of unprotected sexual intercourse (1).World Health Organization (WHO) defines sex as a biopsychological drive that is gradually developed among human children and may continue across their life cycle associated with socio-cultural and environmental factors in which they born and live [2]. Sexual satisfaction is an emotional state that occurs with the fulfillment of individual wishes in the area of sexual life [2]. Healthy sexual relationships lead to achievement of affinity and affection in families in addition to proper satisfaction of sexual instincts [3]. Lack of sexual satisfaction is considered one of the most important problems, impacting an individual's personal and social lives and plays an important role in one's personality development [4]. Sexual satisfaction is affected 
by different factors like job stress, couples' struggles, education level, cultural influences, and economic problems, moral, sexual consistency, physical and mental diseases [5]. Sexual dissatisfaction leads to negative mental and spiritual effects, like disappointment, depression, insecurity, unhappiness, as well as spiritual, mental and personality imbalance. These complications result in diminished ability and creative power, serious conflicts, as well as negative emotions as annoyance, jealousy, competition to suppress each other, lack of self-confidence and being ignored [6] The relationship between sexuality and infertility is bidirectional, as the latter can be either the cause or the consequence of possible sexual disturbances. It has been shown that infertility is the result of underlying sexual disorders in only a minority of cases, while involuntary childlessness itself impairs the individual sexual functioning and the couple' s sexual balance [7]. Several studies have demonstrated that infertile couples have significantly higher rates of sexual satisfaction than fertile couple. Similarly, it has been established that those with secondary infertility have more sexual satisfaction compared with those with primary infertility [8]. The study aimed to assess sexual satisfaction among infertile spouses in Erbil city and to determine associations between the sexual satisfaction and their selected socio demographic characteristics (age, gender, level of education, occupation, income, and residency)

\section{METHODS}

A cross-sectional study was conducted between October, 8, 2018 and October, 8, 2019. A convenience sample of 150 infertile spouses was taken from Maternity Teaching Hospital and three private infertile centers in Erbil city. According to the study's inclusion and exclusion criteria; those who were diagnosed with infertility by a gynecologist were included and infertile spouses with any chronic health condition and psychiatric diseases were excluded. Ethical approval was obtained from Ethical Committee at the College of Nursing, Hawler Medical University in 26, July 2019 (number 77). Furthermore, informed oral consent was taken from the candidate's participation in the study, after confirmation of confidentiality, anonymity and participants self-determination by the researcher. Formal permission was also obtained from Maternity Teaching Hospital and three private infertility centers. The Index of Sexual Satisfaction (ISS) was used to measure sexual satisfaction as a scale which was modified by the researchers. Sensitive questions had been paraphrased in order to be acceptable by the participants, and the 6 points Likert scale was made of 3 points either 0 , none of the time, 1 sometimes, 2 most of the time. The total of the scores obtained from the 19 questions was calculated. The maximum total score for satisfaction was 38 scores. Finally, the spouses were categorized into two groups, those with $>29$ were classified as more satisfied and those with $\leq 29$ were classified as less satisfied Data was analyzed using the Statistical Package through Social Sciences (SPSS, version 22). Categorical variables were presented as proportions, and numerical variables were summarized as means and standard deviations. Chi-square test of association was used to compare proportions. Fisher's exact test was used when the expected count of more than $20 \%$ of the cells of the table was less than 5 . A p-value of $\leq 0.05$ was considered statistically significant.

\section{RESULTS}

Table1 shows that three hundred persons (150 infertile couples) participated in the study. Their mean age was 31.82 with a SD of 6.60 years and ages, ranging from 17-49 
years old. Table 1 also shows that the majority (47.0\%) of them were between 28 -38 years old and only $14.7 \%$ were ages 39 49 years old. The highest percentage (42.6\%) of husbands graduated from institute and college, $19.3 \%$ were high school graduates, and only $2.7 \%$ of them were illiterate. Regarding the wives education most of them (48\%) graduated from college and institute, and $10 \%$ were high school graduates, and only $3.3 \%$ were illiterate. Regarding occupation, the majority $(67.3 \%)$ of husbands were employed and $32.7 \%$ of them were unemployed. The same trend existed in the wives as the majority (69.3\%) were employed and $30.7 \%$ were housewives. The majority $(89.7 \%)$ of the sample in urban areas, and the income of the majority (74\%) was sufficient for daily living Figure 1 showed more than half $(57 \%)$ of participants were less satisfied. The same trend existed in the wives as the majority (69.3\%) were employed and $30.7 \%$ were housewives. The majority (89.7\%) of the sample in urban areas. The income of the majority (74\%) was sufficient for daily living Table 2 showed a significant association was detected within age group 39- 49 years and sexual satisfaction, with wives being less satisfied than their husbands. ( $\mathrm{P}$-value= 0.020 and $P$-value $=0.001$ respectively) . Non-significant associations were detected between sexual satisfaction and level of education, occupation, income and residency.

Table 1: Basic characteristics of study sample

\begin{tabular}{|c|c|c|c|c|c|}
\hline \multirow{2}{*}{$\begin{array}{l}\text { Variables } \\
\text { Age (years) }\end{array}$} & \multicolumn{2}{|r|}{ No. } & \multicolumn{3}{|l|}{$(\%)$} \\
\hline & & & & & \\
\hline $17-27$ & & 115 & (38.3) & & \\
\hline $28-38$ & & 141 & $(47)$ & & \\
\hline $39-49$ & & 44 & $(14.7)$ & & \\
\hline \multicolumn{6}{|c|}{ Mean age $\pm S D$ was $31.82 \pm 6.60$ years } \\
\hline \multicolumn{6}{|c|}{ Gender } \\
\hline \multicolumn{2}{|l|}{ Male } & 150 & $(50)$ & & \\
\hline \multicolumn{2}{|l|}{ Female } & 150 & $(50)$ & & \\
\hline \multicolumn{6}{|l|}{ Residency } \\
\hline & 31 & $(10.3)$ & & \\
\hline \multicolumn{2}{|l|}{ Urban } & 269 & (89.7) & & \\
\hline \multicolumn{6}{|l|}{ Income } \\
\hline \multicolumn{2}{|l|}{ Sufficient for daily living } & 222 & (74) & & \\
\hline \multicolumn{2}{|l|}{ Insufficient } & 40 & $(13.3)$ & & \\
\hline \multirow[t]{2}{*}{ Exceed need } & & 38 & $(12.7)$ & & \\
\hline & \multicolumn{2}{|c|}{ Husband } & & \multicolumn{2}{|c|}{ Wife } \\
\hline Education level & \multicolumn{2}{|c|}{ No. (\%) } & & \multicolumn{2}{|c|}{ No. (\%) } \\
\hline Illiterate & 4 & $(2.7)$ & & 5 & (3.3) \\
\hline Read and write & 0 & (0) & & 3 & $(92)$ \\
\hline Primary school & 23 & $(15.3)$ & & 21 & (14) \\
\hline Secondary school & 25 & $(16.7)$ & & 28 & (18.7) \\
\hline High school & 29 & $(19.3)$ & & 15 & (10) \\
\hline Institute and college graduate & 64 & $(42.6)$ & & 72 & (48) \\
\hline Post-graduate & 5 & $(3.3)$ & & 6 & (4) \\
\hline Total & 150 & $(100)$ & & 150 & $(100)$ \\
\hline \multicolumn{6}{|l|}{ Occupation } \\
\hline \multirow{2}{*}{$\begin{array}{l}\text { Employed } \\
\text { Unemployed }\end{array}$} & 101 & $(67.3)$ & & 104 & $(69.3)$ \\
\hline & 49 & $(32.7)$ & & 46 & $(30.7)$ \\
\hline Total & 150 & (100) & & 150 & $(100)$ \\
\hline
\end{tabular}




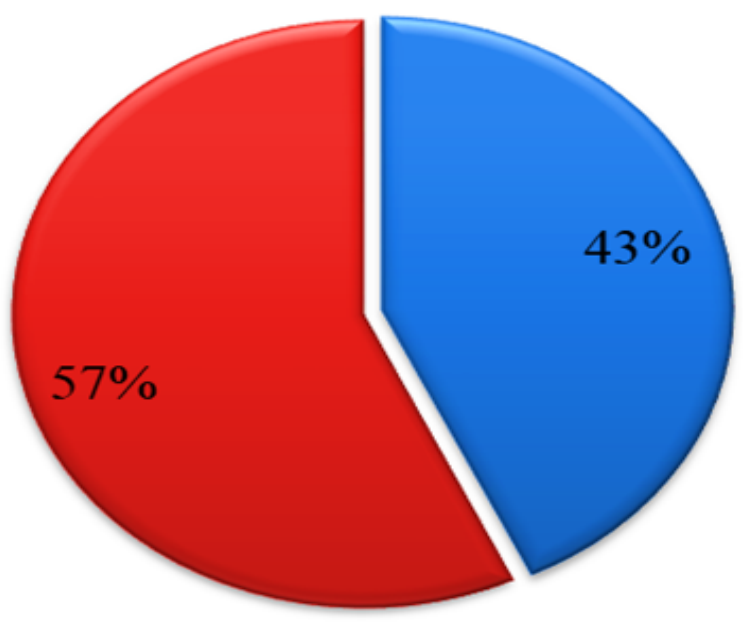

More satisfied

less satisfied

Figure 1: Determine the level of sexual satisfaction

Table 2: Distribution of sample by feeling satisfied with each item of the index of sexual satisfaction

\begin{tabular}{|c|c|c|c|c|c|c|}
\hline \multirow{2}{*}{$\begin{array}{l}\text { Index of Sexual Satisfaction (ISS) } \\
\text { Items }\end{array}$} & \multicolumn{2}{|c|}{$\begin{array}{l}\text { None of the } \\
\text { time }\end{array}$} & \multicolumn{2}{|c|}{ Sometimes } & \multicolumn{2}{|c|}{$\begin{array}{l}\text { Most of the } \\
\text { time }\end{array}$} \\
\hline & No. & (\%) & No. & (\%) & No. & (\%) \\
\hline (1) I feel that my partner enjoys our sex life & 10 & (3.3) & 62 & $(20.7)$ & 228 & (76) \\
\hline (2) Sex is fun for my partner and $\mathrm{m}$ & 213 & (71) & 81 & (27) & 6 & (2) \\
\hline (3) Our sex life is monotonous & 151 & (50.3) & 125 & (41.7) & 24 & (8) \\
\hline (4) When we have sex it is too rushed and hurriedly completed & 66 & $(22)$ & 192 & (64) & 42 & (14) \\
\hline (5) I enjoy the sex techniques that my partner likes or uses & 22 & (7.3) & 182 & $(60.7)$ & 96 & $(32)$ \\
\hline (6) I feel that my partner wants too much sex from me & 58 & $(19.3)$ & 129 & (43) & 113 & (37.7) \\
\hline (7) My partner dwells on sex too much & 46 & $(15.3)$ & 115 & $(38.3)$ & 139 & (46.3) \\
\hline (8) I try to avoid sexual contact with my partner & 14 & (4.7) & 87 & (29) & 199 & (66.3) \\
\hline (9) I feel that sex is a normal function of our relationship & 10 & (3.3) & 85 & $(28.3)$ & 205 & (68.3) \\
\hline (10) My partner does not want sex when I do & 16 & $(5.3)$ & 110 & $(36.7)$ & 174 & (58) \\
\hline (11) I feel that our sex life really adds a lot to our relationship & 13 & (4.3) & 61 & $(20.3)$ & 226 & (75.3) \\
\hline (12) My partner is very sensitive to my sexual needs and desires & 7 & (2.3) & 77 & $(25.7)$ & 216 & (72) \\
\hline (13) I speak about sexuality with my partner & 28 & (9.3) & 165 & $(55)$ & 107 & (35.7) \\
\hline (14) I would live better without sexuality & 206 & $(68.7)$ & 85 & $(28.3)$ & 9 & (3) \\
\hline (15 I reach orgasm during sex & 22 & (7.3) & 101 & $(33.7)$ & 177 & (59) \\
\hline (16) Sexuality scars me & 247 & $(82.3)$ & 47 & $(15.6)$ & 6 & $(2)$ \\
\hline (17) feel that my sex life is boring & 34 & $(11.3)$ & 154 & (51.3) & 112 & (37.3) \\
\hline $\begin{array}{l}\text { (18) I am satisfied with the frequency which I have sexual } \\
\text { intercourse }\end{array}$ & 11 & $(3.6)$ & 102 & (34) & 187 & (62.3) \\
\hline $\begin{array}{l}\text { (19) I am satisfied with the amount of time my partners) and I } \\
\text { spend together immediately after intercourse }\end{array}$ & 8 & (2.6) & 104 & (34.6) & 188 & (62.6) \\
\hline
\end{tabular}


Table 3: Association between Socio-demographic characteristics and sexual satisfaction levels

\begin{tabular}{|c|c|c|c|c|c|c|}
\hline \multirow[t]{3}{*}{ Variables } & & \multicolumn{5}{|c|}{ Sexual Satisfaction Scores } \\
\hline & & \multicolumn{2}{|c|}{ More satisfied } & \multicolumn{2}{|c|}{ Less satisfied } & \multirow[t]{2}{*}{$P$ value } \\
\hline & & No. & (\%) & No. & (\%) & \\
\hline \multirow[t]{3}{*}{ Age( years) } & $17-27$ & 57 & $(49.6)$ & 58 & $(50.4)$ & \\
\hline & $28-38$ & 61 & $(43.3)$ & 80 & $(56.7)$ & \\
\hline & $39-49$ & 11 & $(25)$ & 33 & (75) & $0.020 \mathrm{~S}$ \\
\hline \multirow[t]{2}{*}{ Gender } & Male & 82 & $(54.7)$ & 68 & $(45.3)$ & \\
\hline & Female & 47 & $(31.3)$ & 103 & $(68.7)$ & 0.001 VHS \\
\hline \multirow[t]{8}{*}{ level of education } & Illiterate & 3 & $(33.3)$ & 6 & (66.7) & \\
\hline & Read and write & 0 & (0) & 3 & $(100)$ & \\
\hline & Primary school & 17 & $(38.6)$ & 27 & $(61.4)$ & \\
\hline & Secondary school & 23 & $(43.4)$ & 30 & $(56.6)$ & \\
\hline & High school & 24 & $(54.5)$ & 20 & $(45.5)$ & \\
\hline & Institute graduate & 17 & (32.1) & 36 & $(67.9)$ & \\
\hline & College graduate & 39 & $(47)$ & 44 & (53) & \\
\hline & Post graduated & 6 & $(54.5)$ & 5 & $(45.5)$ & $0.269 \mathrm{NS}$ \\
\hline \multirow[t]{2}{*}{ Occupation } & Employed & 92 & $(44.9)$ & 113 & (55.1) & \\
\hline & Unemployed & 37 & $(38.9)$ & 58 & $(61.1)$ & 0.334 NS \\
\hline \multirow[t]{2}{*}{ Residency } & Rural & 14 & $(45.2)$ & 17 & (54.8) & \\
\hline & Urban & 115 & $(42.8)$ & 154 & $(57.2)$ & 0.797 NS \\
\hline \multirow[t]{3}{*}{ Income } & $\begin{array}{l}\text { Sufficient for daily } \\
\text { living }\end{array}$ & 103 & $(46.4)$ & 119 & $(53.6)$ & \\
\hline & Insufficient & 13 & (32.5) & 27 & (67.5) & \\
\hline & Exceed need & 13 & $(34.2)$ & 25 & (65.8) & $0.133 \mathrm{NS}$ \\
\hline
\end{tabular}

*By Fisher's Exact Test. 


\section{DISCUSSION}

This study was conducted among infertile spouses in Maternity Teaching Hospital and three private infertile centers. The present study demonstrated that more than half of infertile spouses had less sexual satisfaction. A study conducted in Iran found that low sexual satisfaction was less common among infertile couples compared to fertile which was inconsistent with present study [9]. Another supported study also conducted in Iran found that in 292 couples (63.4\%) of them had high sexual satisfaction, and only a few of them $(0.7 \%)$ were dissatisfied which was different from our findings [10]. Regarding age, the current study results indicated that there was a significant association between older ages and sexual satisfaction as, wives were less satisfied compared to their husbands. Results of the current study were in contrast to a study conducted in Japan entitled sexual satisfaction of infertile couples, that they revealed sexual satisfaction of male partners was significantly lower than those of female partners between ages 30 or older [11]. Another study conducted in Iran comparison of quality of life, sexual satisfaction and marital satisfaction between fertile and infertile couples, found that when couple's age decreases the sexual satisfaction increases. Conversely, when couple's age increases, their sexual satisfaction decreases. Considering the fact that increase in age is followed by psychological and social changes in the individuals and the society has a negative attitude toward sexual behaviors in higher ages, increase in age can be mentioned as one of the reasons for reduction of sexual satisfaction [10].The current study results found that no significant association was detected between sexual satisfaction and couple's educational level. A study conducted in Nigeria on sexual dissatisfaction among female patients of reproductive age revealed that a higher educational attainment increases the chance that spouses can speak about their sexual problems [12]. Regarding occupation, the present study's findings indicated that no significant association was found between sexual satisfaction and occupation. The results were consistent with a study's results carried out by Khoei et al. who found no relationship between couples occupation, and sexual sat-isfaction [13]. Regarding residency, the current study showed that sexual satisfaction was not associated with place of living. The present results were supported by a study conducted in Turkey regarding sex. It was found that there was no relationship between place of living and sexual satisfaction [14]. Regarding family income, no association was found between income and sexual satisfaction in this study. A study carried out by Velten and Margraf conducted in Germany about how individual, partner, and relationship factors impact sexual satisfaction within partnerships, differed with the present study as it revealed that income was positively related to sexual satisfaction among spouses, and found that higher socioeconomic status is also associated with better mental and physical health which are correlated with higher sexual satisfaction [15].

\section{CONCLUSION}

The findings of the study indicated that more than half of participants were less satisfied. A significant association was detected between sexual satisfaction and age group (39-49 years), and also wives were less satisfied than their husbands. Infertile spouses especially wives should be educated to increase their awareness regarding sexual issues. 


\section{CONFLICT OF INTEREST}

There is no actual or potential conflict of interest in relation to this study.

\section{REFERNCES}

[1] Gurunath S, Pandian Z, Anderson RA, Bhattacharya S. Defining infertility-a systematic review of prevalence studies. Human Reproduction Update. 2011 14;17 (5):575-88. Available from: https:// www.ncbi.nlm.nih.gov/pubmed/21493634

[2] WHO. Gender, women and health: What do we mean by "sex" and "gender". Geneva $(\mathrm{CH})$ : WHO. 2014. Available from: http:// dx.doi.org/10.2471/BLT.18.211607

[3] Ziherl S, Masten R. Differences in predictors of sexual satisfaction and in sexual satisfaction between female and male university students in Slovenia. Psychiatria Danubina. 2010 29; 22(3):425-9. Available from: https://www.ncbi.nlm.nih.gov/ pubmed/20856186

[4] Toorzani ZM, Zahraei RH, Ehsanpour S, Nasiri M, Shahidi S, Soleimani B. A study on the relationship of sexual satisfaction and common contraceptive methods employed by the couples. Iranian Journal of Nursing and Midwifery Research. 2010; 15(3):115. Available from: https://www.ncbi.nlm.nih.gov , pmc > articles > PMC3093165

[5] Marvi N, Golmakani N, Esmaily H, Shareh H. The Relationship between Sexual Satisfaction and Genital Self-image in Infertile Women. Journal of Midwifery and Reproductive Health. 2018;6(4):1468-75. Available from: https://www.civilica.com > PrintableJR_JMREH-6-4_01.

[6] Heidari AR, Asskary P, Azarkish M. Relation of some demographic factors with marital commitment, sexual satisfaction and life satisfaction in women. Journal of American Science. 2012;8(2):194-9Available from: http://ijfs.ir/library/upload/file/farzad.pdf

[7] Gheshlaghi F, Dorvashi G, Aran F, Shafiei F, Najafabadi GM. The study of sexual satisfaction in Iranian women applying for divorce. International Journal of Fertility \& Sterility. $2014 ; 8(3): 281$. Available from: https:// www.ncbi.nlm.nih.gov/pmc/articles/ PMC4221515.
[8] Piva I, Lo Monte G, Graziano A, Marci R. A literature review on the relationship between infertility and sexual dysfunction: Does fun end with baby making?. The European Journal of Contraception \& Reproductive Health Care. 2014 1; 19(4):231-7. Available from: https:// www.ncbi.nlm.nih.gov/pubmed/24901746

[9] Masoumi SZ, Garousian M, Khani S, Oliaei SR, Shayan A. Comparison of quality of life, sexual satisfaction and marital satisfaction between fertile and infertile couples. International Journal of Fertility \& Fterility. $2016 ; 10(3): 290$. Available from: from: https://www.ncbi.nlm.nih.gov/pmc/ articles/PMC5023039/

[10] Rahmani A, Khoei EM, Gholi LA. Sexual satisfaction and its relation to marital happiness in Iranians. Iranian Journal of Public Health. 2009:77-82. Available from: http:// ijph.tums.ac.ir/index.php/ijph/article/ view/3153

[11] Shoji M, Hamatani T, Ishikawa S, Kuji N Ohta $\mathrm{H}$, Matsui $\mathrm{H}$, et al. Sexual Satisfaction of infertile couples assessed using the Golombok-Rust Inventory of Sexual Satisfaction (GRISS). Scientific Reports. 2014 6;4:5203. Available from: https:// www.nature.com/articles/srep05203

[12] Fajewonyomi BA, Orji EO, Adeyemo AO. Sexual dysfunction among female patients of reproductive age in a hospital setting in Nigeria. Journal of Health, Population, and Nutrition. 2007 ;25(1):101. Available from: https://www.ncbi.nlm.nih.gov/ pubmed/17615910

[13] Khoei EM, Maasoumi R, Talebi S, Hajimirzaie $S$, Bayat A, Rimaz $S$, et al. Factors Affecting Sexual Satisfaction in Iranian Women. Women's Health Bulletin. 2015;2 (4). Available from: https:// www.ncbi.nlm.nih.gov/pmc/articles/ PMC4221515/

[14] Dundon CM, Rellini AH. More than sexual function: Predictors of sexual satisfaction in a sample of women age 40-70. The Journal of Sexual Medicine. 2010 1;7(2):896904. Available from: https:// www.ncbi.nlm.nih.gov/pubmed/19889146

[15] Velten J, Margraf J. Satisfaction guaranteed? How individual, partner, and relationship factors impact sexual satisfaction within partnerships. Plos One. 2017 23;12 (2):e0172855. Available from: https:// www.ncbi.nlm.nih.gov/pubmed/28231314. 